\title{
Production of Innocuous Guinea Pig Meat with Native Probiotic Enriched with Omega 3 Fatty Acids
}

\section{Guevara J1*, Carcelén $\mathrm{F}^{2}$, Bezada $\mathrm{S}^{2}$, Núñez $0^{1}$, Pachas $\mathrm{J}^{3}$ Vergaray $\mathrm{Ry}^{3}$}

${ }^{1}$ Professor of the Academic Department of Processes, Faculty of Chemistry and Chemical Engineering, San Marcos Major National University

${ }^{2}$ Professor of the Faculty of Veterinary Medicine, San Marcos Major National University ${ }^{3}$ Students from the EP of Agroindustrial Engineering, Faculty of Chemistry and Chemical Engineering, San Marcos Major National University

*Corresponding author: Jorge Ernesto Guevara Vásquez, Professor of the Academic Department of Processes, Faculty of Chemistry and Chemical Engineering, San Marcos Major National University, Tel: 966132000; Email: guevaravet@hotmail.com

\section{Abstract}

The aim of this paper was producing innocuous meat of guinea pig enriched with omega-3 fatty acids by supplementing diets with fish oil and native probiotic in order to replace growth-promoting antibiotics. We used 180 weaned guinea pigs, they were 14 days old on average and were distributed in 9 different treatments. A Factorial Design $3 \times 3$ was used, with 10 replicates and 2 animals per each replicate. The results were assessed with the statistical package INFOSTAT. The meat of guinea pigs fed with $1 \%$ fish oil diet contained $0.28 \%$ of omega - 3 fatty acids $(0.18 \%$ of DHA and $0.1 \%$ of EPA) and the meat of guinea pigs fed with $2 \%$ diet fish oil recorded a value of $0.65 \%$ AG omega-3 (0.47\% of DHA and $0.18 \%$ of EPA). The results of monounsaturated fatty acids (25.12\%) and saturated $(29.19 \%)$ of guinea pigs fed $1 \%$ of fish oil, were higher than those of the control diet. The meat of the guinea pigs that received the highest percentage of fish oil ( $1 \%$ and $2 \%$ ) and 1.5 and $3 \mathrm{ml}$ of native probiotic had the highest percentages of dry matter and the lowest percentages of moisture. The best percentages of protein and ethereal extract, as well as ash and non-nitrogenous extract presented the guinea pigs that were fed with $2 \%$ of fish oil and $3 \mathrm{ml}$ of native probiotic. The meat of the guinea pigs supplemented with $1 \%$ and $2 \%$ of fish oil and 1.5 and $3 \mathrm{ml}$ of native probiotic do not show any organoleptic differences with those of the control diet, which ensures consumer acceptability. The best productive parameters were achieved in guinea pigs that were supplemented with $2 \%$ fish oil and $3 \mathrm{ml}$ native probiotic, with no statistically significant difference.

Keywords: Guinea Pig (Cavia porcellus); Innocuous Meat; Native Probiotic; Fatty Acids; Omega 3 


\section{Bioequivalence \& Bioavailability International Journal}

\section{Introduction}

All livestock farming aims to achieve a high birth rate, excellent weight gain and faster growth. This is so that the majority of guinea pigs farms when being handled traditionally do not reach their objectives and looking for a better production they resort to the use of antibiotics for prophylactic and therapeutic purposes, abusing of the nutrients in the feed, for which there is a greater gain of weight. However, the inappropriate use and overdose used in the delivery of this product results in the formation of bacteria resistant to common antibiotics, constituting the use of probiotics in a good natural alternative for this problem and without side effects to improve the intestinal functioning and, by extension, optimize the health and improve the productive parameters.

Nowadays many diseases are affecting mankind, which is indicated by some research that comes from bad eating habits. It is considered long chain omega- 3 fatty acids being among the most favorable nutrients for human health. The higher animals and human beings depend on the dietary supply of fatty acids given the inability of double bond synthesis at the position 3 of the fatty acids.

Omega-3 can be used in the diet of animals to enrich their meat. Guinea pig meat is consumed in different regions in Peru and given the importance of the search for quality food and that has in its composition fatty acids mentioned before by the benefits it provides was produced innocuous meat of guinea pig enriched with omega 3 fatty acids by supplementing the diets with fish oil and native probiotic in replacement of growthpromoting antibiotics.

\section{Materials and Methods}

The present research was carried out in the guinea pig farm specially prepared for the development of this study, located at Professional School of Agroindustrial Engineering of San Marcos Major National University in San Juan de Lurigancho District - Lima city. The feed used in the control treatment of the present experimental work was formulated using Mixit-2 plus software for monogastric animals. Forage was fresh alfalfa in $10 \%$ of the live weight for which the animals were weighed each week, this was the reference and was increasing as weekly increased the weight of the animals. The forage was distributed every day in two parts one-half in the morning and the other half in the afternoon.

The native probiotic was obtained from previously isolated strains of epithelium and intestinal sections of guinea pigs (Cavia porcellus) neonates (1-7 days old), Which were previously identified by molecular techniques based on sequencing and bioinformatics analysis of the 16S rDNA gene. Raw fish oil was used, because it has a higher fatty acid content than the acidified and refined oil, also because its lower AGS content and its higher AGPI value.

Nine treatments were evaluated:

T1: Diet $+0 \%$ Fish Oil $+0.0 \mathrm{ml}$ de Native Probiotic

T2: Diet $+0 \%$ Fish Oil $+1.5 \mathrm{ml}$ de Native Probiotic

T3: Diet $+0 \%$ Fish Oil $+3.0 \mathrm{ml}$ de Native Probiotic

T4: Diet $+1 \%$ Fish Oil $+0.0 \mathrm{ml}$ de Native Probiotic T5: Diet $+1 \%$ Fish Oil $+1.5 \mathrm{ml}$ de Native Probiotic

T6: Diet $+1 \%$ Fish Oil $+3.0 \mathrm{ml}$ de Native Probiotic

T7: Diet $+2 \%$ Fish Oil $+0.0 \mathrm{ml}$ de Native Probiotic

T8: Diet $+2 \%$ Fish Oil $+1.5 \mathrm{ml}$ de Native Probiotic

T9: Diet $+2 \%$ Fish Oil $+3.0 \mathrm{ml}$ de Native Probiotic

180 guinea pigs were used, which were distributed in 9 treatments and 10 replicates per treatment, where each replicate consisted of 2 animals. The animals were placed in a prefabricated shed with calamine roof. 90 cages and bedding for guinea pig $0.5 \mathrm{~m}$ long by $0.5 \mathrm{~m}$ wide and 0.37 $\mathrm{m}$ high were used, with one feeder and one water container percage. A balance of $3 \mathrm{~kg}$ of capacity was used with a sensitivity of $2 \mathrm{~g}$ for the weight control of animals and food.

The parameters evaluated were:

\section{Quality Parameters}

- Chromatographic analysis of fatty acids

- Physical and chemical analysis

- Sensory evaluation

\section{Productive Parameters}

- Food Consumption

- Weight gain and weight gain

- Food conversion

- Housing performance

- Mortality and morbidity

\section{Results and Discussion}

\section{Chromatographic Analysis of Guinea Pig Meat}

Table 1 shows the content of omega - 3 fatty acids (AG) expressed as percentage and $\mathrm{mg} / 100 \mathrm{~g}$ of meat fat. It is observed that the meat of guinea pigs fed with the $1 \%$ fish oil diet contains $0.28 \%$ of omega - 3 fatty acids $(0.18 \%$ of DHA and $0.1 \%$ of EPA) and the meat of guinea pigs fed the diet $2 \%$ of fish oil recorded a value of $0.65 \%$ AG omega- 3 $(0.47 \%$ of DHA and $0.18 \%$ of EPA). In absolute terms, the 
values $0.28 \%$ and $0.65 \%$ of omega-3 AG corresponded to 30.67 and $73 \mathrm{mg}$ of (EPA + DHA) / $100 \mathrm{~g}$ of meat, respectively.

The omega - 3 content of guinea pig meat fed the diet containing $2 \%$ of fish oil was $40 \%$ higher than the diet supplemented with $1 \%$ fish oil. These results confirm the omega - 3 (EPA and DHA) present in guinea pig meat, come from fish oil since the meat of guinea pigs that consumed the control diet did not present such fatty acid.

Guevara (2009) found $280 \mathrm{mg}$ omega-3 / 100g of guinea pig meat, which were fed with diets of $1 \%$ fish oil, this value is higher than $30.67 \mathrm{mg}$ omega-3 / 100g meat found in this investigation [1]. The age of guinea pigs in the present study was lower than those reported by Guevara, which has been able to influence the fatty acid fixation and accumulation of fat in animals. On the other hand, the values of $30.67 \mathrm{mg}$ and $73 \mathrm{mg}$ of (EPA + DHA) / $100 \mathrm{~g}$ of meat found in the present study are lower than those reported by Rojas (2002) 60 and 57 mg AG omega-3 / $100 \mathrm{~g}$ meat of guinea pigs that were fed diets of $1 \%$ fish oil $+5 \%$ fish meal and with only $1 \%$ fish oil, respectively
[2]. This difference in the amount of fatty acids fixed in guinea pig meat is also related to the average age of guinea pigs used in both investigations; what we can corroborate is the increase of fatty acids in the meat when the percentages of fish oil in the diets are increased.

\section{Saturated and Unsaturated Fatty Acids in Guinea Pig Meat}

Table 2 shows the percentage values of saturated, monounsaturated and polyunsaturated fatty acids in guinea pig meat. The results show that the guinea pigs that received the control diet had the highest level of polyunsaturated fatty acids (46.57\%), unlike those fed the diet supplemented with $1 \%$ fish oil (44.96\%). However, the results of monounsaturated $(25.12 \%)$ and saturated fatty acids (29.19\%) of guinea pigs fed $1 \%$ of fish oil, are higher than those of the control diet.

The meat of guinea pig that received the diet with $2 \%$ of fish oil has the lowest level of polyunsaturated fatty acids (43.28\%) and the highest level of monounsaturated acids $(25.76 \%)$ and saturated fatty acids $(30.46 \%)$.

\begin{tabular}{|c|c|c|c|c|c|c|c|}
\hline \multicolumn{2}{|c|}{ TREATMENTS } & EPA & DHA & $\begin{array}{c}\text { Total Omega } 3 \\
\text { (EPA + DHA) }\end{array}$ & $\begin{array}{c}\text { Oleic } \\
(\text { Omega -9) }\end{array}$ & $\begin{array}{c}\text { Linoleic } \\
(0 m e g a-6)\end{array}$ & $\begin{array}{c}\text { Alpha Linolenic } \\
\text { (Omega 3) }\end{array}$ \\
\hline \multirow[t]{2}{*}{ OAP + 0 PN } & $\%$ & ND & ND & ND & 20.75 & 42.88 & 4.99 \\
\hline & $\mathrm{mg} / 100 \mathrm{~g}$ & ND & ND & ND & 1964 & 4058 & 472 \\
\hline \multirow[t]{2}{*}{$\mathrm{OAP}+1.5 \mathrm{PN}$} & $\%$ & ND & ND & ND & 23.19 & 37.78 & 4.52 \\
\hline & $\mathrm{mg} / 100 \mathrm{~g}$ & ND & ND & ND & 2261 & 3684 & 441 \\
\hline \multirow[t]{2}{*}{ OAP + 3.0PN } & $\%$ & ND & ND & ND & 22.13 & 39.08 & 5.03 \\
\hline & $\mathrm{mg} / 100 \mathrm{~g}$ & ND & ND & ND & 2116 & 3735 & 481 \\
\hline \multirow[t]{2}{*}{$1 \mathrm{AP}+0 \mathrm{PN}$} & $\%$ & 0.09 & 0.16 & 0.25 & 23 & 38.6 & 4.43 \\
\hline & $\mathrm{mg} / 100 \mathrm{~g}$ & 10 & 17 & 27 & 2441 & 4096 & 470 \\
\hline \multirow{2}{*}{$1 \mathrm{AP}+1.5 \mathrm{PN}$} & $\%$ & 0.10 & 0.21 & 0.31 & 22.48 & 37.99 & 4.66 \\
\hline & $\mathrm{mg} / 100 \mathrm{~g}$ & 11 & 23 & 34 & 2493 & 4213 & 517 \\
\hline \multirow{2}{*}{$1 \mathrm{AP}+3.0 \mathrm{PN}$} & $\%$ & 0.11 & 0.18 & 0.29 & 22.18 & 39.33 & 4.66 \\
\hline & $\mathrm{mg} / 100 \mathrm{~g}$ & 12 & 19 & 31 & 2332 & 4136 & 490 \\
\hline \multirow{2}{*}{$2 \mathrm{AP}+0 \mathrm{PN}$} & $\%$ & 0.19 & 0.58 & 0.77 & 22.44 & 35.34 & 4 \\
\hline & $\mathrm{mg} / 100 \mathrm{~g}$ & 21 & 65 & 86 & 251 & 3953 & 447 \\
\hline \multirow{2}{*}{$2 \mathrm{AP}+1.5 \mathrm{PN}$} & $\%$ & 0.21 & 0.41 & 0.62 & 22.83 & 36.52 & 4.04 \\
\hline & $\mathrm{mg} / 100 \mathrm{~g}$ & 24 & 46 & 70 & 2575 & 4120 & 456 \\
\hline \multirow{2}{*}{$2 \mathrm{AP}+3.0 \mathrm{PN}$} & $\%$ & 0.15 & 0.41 & 0.56 & 22.23 & 37.71 & 4.44 \\
\hline & $\mathrm{mg} / 100 \mathrm{~g}$ & 17 & 46 & 63 & 2486 & 4218 & 497 \\
\hline
\end{tabular}

Source: ITP

Table 1: Profile of omega-3 fatty acids in guinea pig meat. 


\section{Bioequivalence \& Bioavailability International Journal}

\begin{tabular}{|c|c|c|c|c|c|c|}
\hline \multirow{2}{*}{ Treatments } & \multicolumn{2}{|c|}{ Saturated } & \multicolumn{2}{|c|}{ Monounsaturated } & \multicolumn{2}{|c|}{ Poliunsaturated } \\
\hline & $\%$ & $\mathrm{mg} / 100 \mathrm{~g}$ & $\%$ & $\mathrm{mg} / 100 \mathrm{~g}$ & $\%$ & $\mathrm{mg} / 100 \mathrm{~g}$ \\
\hline OAP + 0 PN & 27.68 & 2620 & 22.54 & 2134 & 49.24 & 4648 \\
\hline $0 \mathrm{AP}+1.5 \mathrm{PN}$ & 30.20 & 2945 & 25.35 & 2472 & 43.85 & 4277 \\
\hline OAP + 3.0PN & 29.55 & 2825 & 24.24 & 2317 & 45.62 & 4361 \\
\hline $1 \mathrm{AP}+0 \mathrm{PN}$ & 29.18 & 3097 & 25.46 & 2702 & 44.60 & 4704 \\
\hline $1 \mathrm{AP}+1.5 \mathrm{PN}$ & 29.54 & 3277 & 25.09 & 2783 & 44.58 & 4944 \\
\hline $1 \mathrm{AP}+3.0 \mathrm{PN}$ & 28.85 & 3034 & 24.81 & 2608 & 45.68 & 4804 \\
\hline $2 \mathrm{AP}+0 \mathrm{PN}$ & 31.33 & 3504 & 25.63 & 2867 & 42.49 & 4751 \\
\hline $2 \mathrm{AP}+1.5 \mathrm{PN}$ & 30.09 & 3395 & 26.42 & 2980 & 42.91 & 4841 \\
\hline $2 \mathrm{AP}+3.0 \mathrm{PN}$ & 29.97 & 3352 & 25.22 & 2820 & 44.43 & 4970 \\
\hline
\end{tabular}

*These values correspond to the average of three samples per treatment.

Source: ITP

Table 2: Fatty acids in guinea pig meat $\left({ }^{*}\right)$.

These results are similar to those published by Antúnez de Mayolo (1999), who found in guinea pigs more polyunsaturated fatty acids (38.79); followed by saturated fatty acids (34.56) and finally monounsaturated fatty acids (22.46 mg / $100 \mathrm{~g}$ fat). Similar results to those published by Guevara (2009). Even though this author used guinea pigs in his experiment and only with $1 \%$ fish oil plus sacha inchi (Plukenetia volubilis) $[3,4]$.

\section{Proximal Analysis of Guinea Pig Meat}

In Table 3, the results of the proximal physical analysis of guinea pig meat are presented, according to the evaluated parameters, it is observed the meat of the guinea pigs that received the highest percentage of fish oil (1 and 2\%) presented the highest percentages of dry matter, as well as the meat of the guinea pigs that received 1.5 and $3 \mathrm{ml}$ of native probiotic presented the highest percentages of dry matter and the lowest percentages of humidity.

Noting the combination of fish oil and native probiotic as part of the food ration favors the percentages of proximal physical analysis of the guinea pig meat.

The results of the proximal chemical analysis of the guinea pig of the different treatments are shown in Table 6 , it can be seen that the best percentages of proteins and ethereal extract, as well as ashes and non-nitrogenous extract, presented guinea pigs that were fed with $2 \%$ crude fish oil in their diets unlike those that were supplied with $1 \%$ fish oil and without fish oil. Regarding the native probiotic follows the same trend as the fish oil, better percentages with the supply of 1.5 and $3 \mathrm{ml}$ of native probiotic. This shows that the nutritional values of increasing fish oil in the guinea pigs diet gives a favorable benefit to the consumer.

\begin{tabular}{|c|c|c|c|c|c|c|c|c|c|c|}
\hline \multirow{2}{*}{ Treatment } & \multirow{2}{*}{ Moisture } & \multirow{2}{*}{ Dry matter } & \multicolumn{2}{|c|}{ Proteins (\%) } & \multicolumn{2}{c|}{ Ethereal extract (\%) } & \multicolumn{2}{|c|}{ Ash (\%) } & \multicolumn{2}{c|}{$\begin{array}{c}\text { Non-nitrogenous } \\
\text { extract (\%) }\end{array}$} \\
\cline { 3 - 11 } & & & wet & dry & wet & dry & wet & dry & wet & dry \\
\hline 0AP + 0 PN & 68.34 & 31.66 & 22.07 & 69.72 & 6.64 & 20.97 & 2.4 & 7.57 & 0.55 & 1.74 \\
\hline 0AP+ 1.5PN & 72.17 & 27.83 & 14.95 & 53.72 & 10.38 & 37.31 & 1.49 & 5.36 & 1.01 & 3.61 \\
\hline 0AP+ 3.0PN & 73.63 & 26.37 & 16.4 & 62.19 & 8.32 & 31.55 & 1.54 & 5.84 & 0.11 & 0.42 \\
\hline 1AP+ 0 PN & 75.92 & 24.08 & 15.81 & 65.66 & 5.46 & 22.67 & 1.3 & 5.42 & 1.51 & 6.25 \\
\hline 1AP+ 1.5PN & 72.22 & 27.78 & 16.91 & 60.87 & 8.84 & 31.84 & 1.26 & 4.52 & 0.77 & 2.77 \\
\hline 1AP+ 3.0PN & 69.61 & 30.39 & 21.05 & 69.26 & 5.44 & 17.91 & 2.42 & 7.95 & 1.48 & 4.88 \\
\hline 2AP+ 0 PN & 72.01 & 27.99 & 15.97 & 57.05 & 8.53 & 30.49 & 1.99 & 7.11 & 1.5 & 5.35 \\
\hline 2AP+ 1.5PN & 68.79 & 31.21 & 22.63 & 72.51 & 6.6 & 21.13 & 1.81 & 5.79 & 0.17 & 0.57 \\
\hline 2AP+ 3.0PN & 68.1 & 31.9 & 18.93 & 59.34 & 10.95 & 34.32 & 1.54 & 4.83 & 0.48 & 1.51 \\
\hline
\end{tabular}

*These values correspond to the average of three samples per treatment.

Table 3: Proximal analysis of guinea pig meat $\left({ }^{*}\right)$.

These results coincide with those reported by Guevara (2015), despite the fact that the author in his research froze the meat at $-20{ }^{\circ} \mathrm{C}$ without using any additives for conservation, and also used a pre-cooking time of 3 
minutes, unlike Valencia (2007), who used ascorbic acid and sodium chloride, used 15 minutes of cooking and a storage temperature of $4^{\circ} \mathrm{C}$; however, similar results are presented when the quality of guinea pig meat is not altered [5].

\section{Sensory Evaluation}

The information on the sensorial analysis is shown in Table 4. The taster panelists, who were familiar with guinea pig meat, gave as a consensus that all samples of guinea pig meat were of very good texture, juiciness and flavor. This demonstrates that the use of $1 \%$ and $2 \%$ fish oil in guinea pig diets does not affect the organoleptic characteristics of guinea pig meat.

When performing the scalar difference of the results, referring to the preference for the meat of guinea pigs of the different treatments, it was observed that there are no significant differences between the samples on the preferences of the guinea pig meat that received the different experimental diets (treatments). Regarding the color, odor, taste and juiciness of guinea pig meat of the various treatments, statistical analyses were also not found significant differences between treatments.

\begin{tabular}{|c|c|c|}
\hline Treatment & Tasters & Average \\
\hline Diet Control & 6 & 3.656 \\
\hline 1\% raw fish oil & 6 & 3.903 \\
\hline 2\% raw fish oil & 6 & 3.878 \\
\hline
\end{tabular}

Table 4: Taste of guinea pig meat from different treatments.

These results agree with Guevara (2009), who used 1\% of fish oil and $4 \%$ of sacha inchi seed (Plukenetia volubilis), the results are similar even though in the present investigation we used $2 \%$ of fish oil [4].

Results that were different from those published by Hulan and Ackman (1990), who found fishy taste in the

\begin{tabular}{|c|c|c|c|c|c|}
\hline \multirow[b]{2}{*}{ Treatmen } & \multicolumn{5}{|c|}{ Productive parameters } \\
\hline & $\begin{array}{c}\text { Food } \\
\text { Consumptior } \\
\text { (g) }\end{array}$ & $\begin{array}{c}\text { Final } \\
\text { weight } \\
\text { (g) }\end{array}$ & $\begin{array}{c}\text { Weigh } \\
\text { gain } \\
\text { (g) }\end{array}$ & \begin{tabular}{|c|} 
Food \\
conversion \\
(g)
\end{tabular} & $\begin{array}{l}\text { Carcas } \\
\text { yield } \\
\text { (\%) }\end{array}$ \\
\hline $\begin{array}{c}\text { OAP + } 0 \\
\text { PN }\end{array}$ & $1191.7^{a}$ & $838.1^{\mathrm{a}}$ & 361.6 & $2.3^{\mathrm{a}}$ & $68.8^{a}$ \\
\hline $\begin{array}{l}\text { OAP + } \\
1.5 P N\end{array}$ & $1306.9^{a}$ & $841.6^{\mathrm{a}}$ & 370.4 & $2.3^{\mathrm{a}}$ & $69.0^{a}$ \\
\hline $\begin{array}{l}\text { OAP + } \\
\text { 3.0PN }\end{array}$ & $1254.5^{a}$ & $787.7^{\mathrm{a}}$ & $317.7 \mathrm{a}$ & 2.9 a & $64.6^{\mathrm{a}}$ \\
\hline $\begin{array}{c}\text { 1AP + } 0 \\
\text { PN }\end{array}$ & 1246.7 a & $820.8^{a}$ & $347.2^{a}$ & $2.4^{\mathrm{a}}$ & $70.5^{\mathrm{a}}$ \\
\hline 1AP + & $1333.5^{\mathrm{a}}$ & $833.6^{\mathrm{a}}$ & $363.0 \mathrm{a}$ & $2.5 \mathrm{a}$ & $69.6^{a}$ \\
\hline
\end{tabular}

meat of consuming animals, are due to the fact that these authors did not balance the inputs used in the food ration, probably used high percentages of oil and fish meal in their diet [6].

\section{Productive Parameters}

\section{Food Consumption, Weight and Weight Gain, Feed Conversion and Carcass Yield}

Table 5 shows the results of the production parameters of guinea pigs supplemented with fish oil and native probiotic, where it is observed that the consumption of the total average feed referring to the diet with $2 \%$ of raw fish oil it was found to be high compared to other dietary regimes; the control diet and diet with 1\% raw fish oil which had slightly similar values.

It was determined that the guinea pigs fed the diet $2 \%$ crude fish oil achieved greater weight at the end of the experiment and greater weight gain with respect to other dietary regimes. On the other hand, the weight gains achieved in this research are comparable to those obtained in the commercial farms of guinea pigs.

The feed conversion of guinea pigs receiving $2 \%$ fish oil in their diets was slightly lower than those receiving $1 \%$ fish oil and the control diet. A higher carcass yield was observed in guinea pigs fed the diet with $1 \%$ and $2 \%$ raw fish oil, followed by those receiving the control diet. Noting that with the native probiotic supplement was observed in the guinea pigs a trend similar to the productive behavior that with fish oil. Statistical analysis showed that all productive parameters analyzed did not present statistical difference between treatments and when the Duncan test was performed, no statistical difference was found either. However there is a numerical difference in favor of guinea pigs that received fish oil and native probiotic.

\begin{tabular}{|c|c|c|c|c|c|}
\hline $\mathbf{1 . 5 P N}$ & & & & & \\
\hline $\begin{array}{c}\mathbf{1 A P}+ \\
\mathbf{3 . 0 P N}\end{array}$ & $1271.5^{\mathrm{a}}$ & $816.6^{\mathrm{a}}$ & $340.5^{\mathrm{a}}$ & $2.8^{\mathrm{a}}$ & $69.3^{\mathrm{a}}$ \\
\hline $\begin{array}{c}\mathbf{2 A P}+\mathbf{0} \\
\mathbf{P N}\end{array}$ & $1368.7^{\mathrm{a}}$ & $861.9^{\mathrm{a}}$ & $365.6^{\mathrm{a}}$ & $2.4^{\mathrm{a}}$ & $69.4^{\mathrm{a}}$ \\
\hline $\begin{array}{c}\mathbf{2 A P +} \\
\mathbf{1 . 5 P N}\end{array}$ & $1318.8^{\mathrm{a}}$ & $887.0^{\mathrm{a}}$ & $385.9^{\mathrm{a}}$ & $2.2^{\mathrm{a}}$ & $70.0^{\mathrm{a}}$ \\
\hline $\begin{array}{c}\mathbf{2 A P +} \\
\mathbf{3 . 0 P N}\end{array}$ & $1395.2^{\mathrm{a}}$ & $818.6^{\mathrm{a}}$ & $353.7^{\mathrm{a}}$ & $2.7^{\mathrm{a}}$ & $69.8^{\mathrm{a}}$ \\
\hline
\end{tabular}

The same letters in columns indicate there is no statistical difference $(\mathrm{p}>0.05)$

Table 5: Evaluation of the production parameters of guinea pigs supplemented with fish oil and native probiotic. 


\section{Bioequivalence \& Bioavailability International Journal}

Guevara (2015) found feed conversion values between 3.47 and 3.73. Cerna (1997) found it between 3.03 and 3.26 and Rivas (1995) found it between 3.81 and 4.12, these values are higher than those reported in the present investigation, indicating that there is a productive, efficient and affordable behavior to what is achieved in the commercial farms of guinea pigs with the advantage that the meat of guinea pig contains omega-3 AG benefit of consumer health. This productive parameter with reference to the diet with $1 \%$ of raw fish oil being the value obtained of $69.8 \%$ that turned out to have a greater percentage compared with that registered by Guevara (2015) of $69.45 \%$ of carcass yield [7].

\section{Conclusions}

At the end of this research, the following conclusions were reached:

- The supplementation with $1 \%$ and $2 \%$ of fish oil in its diets and with native probiotic replacing growthpromoting antibiotics, it was possible to produce innocuous guinea pig meat and also enriched with omega -3 EPA and DHA fatty acids

- The meat of the guinea pigs that were supplemented with 1 and $2 \%$ of fish oil and 1.5 and $3 \mathrm{ml}$ of native probiotic does not show any organoleptic differences with those of the control diet, which ensures the acceptability of the consumed.

- The best productive parameters were guinea pigs which were supplemented with $2 \%$ fish oil and $3 \mathrm{ml}$ of native probiotic, with no statistically significant difference

\section{References}

1. Guevara J (2016) Enriquecimiento de la carne de cuy con ácidos grasos omega-3 mediante la suplementación de las dietas con aceite de pescado y semillas de sacha inchi. REV INV VET Perú 27(1): 4550 .

2. Rojas S (2002) El aceite de Pescado Fuente de Omega3 para el Desarrollo de Productos Enriquecidos. Pesca responsable. Revista de la SNP. Año VI, № 26. Lima Perú.

3. Antunez De Mayolo S (1999) El cuy excelente nutriente. Una latente contribución del Incanato. El Comercio. 13.02.2000. Lima.

4. Guevara J (2009) Enriquecimiento de la carne de cuy con ácidos grasos omega 3 mediante la suplementación de las dietas con aceite de pescado y semillas de sacha inchi. Tesis Ph.D. UNALM. LimaPerú.

5. Valencia Po (2007) La optimización del tiempo de precocido de las carcasas crudas de cuy (Cavia porcellus) y su incidencia en el tiempo de vida útil. Tesis. Facultad de Ciencia e Ingeniería en Alimentos. Universidad Técnica de Ambato. Ecuador.

6. Hulan HY, Ackman R (1990) Incorporating Omega-3 Fatty Acid into Chicken Product Lipids. Department of Biochemishy. Memorial University of Newfoundland.

7. Cerna A (1997) Evaluación de cuatro niveles de residuo cervecería seco en el crecimiento y engorde de cuyes. Tesis. Facultad de Zootecnia. Universidad Nacional Agraria La Molina. Lima. pp: 63.

8. ITP (Instituto Tecnológico Pesquero Del Perú) (2016) Lima - Perú. 